\title{
Do Investors Make Abnormal Returns Consistently? An Econometric Investigation in the Nigerian Capital Market
}

\author{
Ayakeme Ebiwarefa Whisky ${ }^{1} \&$ Chinedu B. Ezirim ${ }^{1}$ \\ ${ }^{1}$ Department of Finance and Banking, Faculty of Management Sciences, University of Portharcourt, River State, \\ Nigeria \\ Correspondence: Ayakeme Ebiwarefa Whisky, Department of Finance and Banking, Faculty of Management \\ Sciences, University of Portharcourt, River State, Nigeria. E-mail: ajibolaarewa@yahoo.com
}

Received: December 16, 2013

Accepted: February 5, $2014 \quad$ Online Published: March 31, 2014

doi:10.5430/ijfr.v5n2p115

URL: http://dx.doi.org/10.5430/ijfr.v5n2p115

\begin{abstract}
The study focused on the intriguingly interesting controversy whether "investors can make abnormal return consistently in the Nigerian capital market?" It employs monthly return data in the Nigerian stock exchange to estimate a non-parametric model which shows that the observed z-statistic is larger than the critical at $5 \%$ in all the sub-periods and the overall period. The study thus concludes that investors can make abnormal returns in the Nigerian capital market.
\end{abstract}

Keywords: abnormal returns, efficient market hypothesis, Nigerian capital market, Z-statistic

\section{Introduction}

The contention whether investors can make abnormal returns consistently has assumed topical interest in capital market literature since Fama (1965) popularized the efficient market hypothesis. The debate has attracted pronounced and entrenched interest from academics, with both sides advancing empirical validity to buttress their positions. The kernel of the efficient market theory argues that no investor can make abnormal return given a free flow of information set to all market participants. However, it is a truism that market conditions, as dynamic as they are relative to the prevailing economic circumstances could impact changes which could alter well known positions and permit investors the leverage of earning higher than average returns in the market. Whether such earnings are short-lived or sustainable enough to obviate the relevance of the efficient market theory is contentious.

We observe that previous studies on the efficiency of the Nigeria capital market by Samuel and Yacout (1981), Ayadi (1984), Olowe (1999), Emenike (2008) and Adelegan (2009) were basically concerned about determining the form of efficiency of the market. Their findings confirm the Nigerian capital market as either weak form efficient or semi-strong form efficient. None of these studies however investigated the possibility of investors making abnormal returns or using the parlance of Fama (1969) "beat the market". The confirmation of the Nigerian capital market as either weak form efficient or semi-strong form efficient presupposes that investors cannot make abnormal returns consistently.

Yet, Ogege and Ezike (2012) argue that an operationally efficient stock market may not be informationally efficient. This in our consideration is fundamental because the concept of linear relationship between risk and return subsumes commensurate return on asset at whatever level of risk and this is central to modern portfolio theory. The significance of this study therefore is the gap in the existing Nigerian literature on the Efficient Market Hypothesis as it intends to investigate whether investors can consistently make abnormal returns. However, the rest of the paper is as follows: literature reviews, methodology and data, results, conclusion and recommendations

\section{Literature Review}

Echekoba et al (2012) argue that the concept of stock prices following a random walk, which implies that stock prices change randomly and in an unpredictable manner is an important corollary of the Efficient Market Hypothesis. The authors reported Ball, et al (1999) as saying that stock returns reflect new market level and firm level information. Basu (1988) according to Echekoba, et al (2012) stated that the extent to which stocks move together depends on the relative amount of firm level and market wide information capitalized into stock prices. They thus 
concluded that it is hard to profit from even the most extreme violation of market efficiency because stock market anomalies are only too often chance events that do not persist into the future.

However, Ziobrowski et al (2011) in investigating the information efficiency regressed the calendar-time portfolio returns of the entire sample of stocks on the Fama-French three-factor model (augmented by momentum) and discovered that stocks purchased by members of the US House of Representatives earn statistically significant positive abnormal returns. The returns outperformed the market by 55 basis points per month (over $6 \%$ annually). The premise for this discovery was that Senators and House Members possess significant information advantages over other market participants.

Seyhun (1985) in investigating the anomalous findings of previous studies used the market model, which is a statistical model based on the joint normality of the distribution of security returns, to examine the daily returns files of 769 firms involving 1.5 million insider transactions from 1975 to 1981 compiled by the Center for Research in Security prices (CRSP) to determine its predictive effect. The study indicated that insiders can predict abnormal future stock price changes.

Dogu, et al (2010) examined whether the buying and selling decisions of insiders can permit excess returns by reviewing 4564 different information forms relating to 213 listed companies which by the operating regulation of the Istanbul Stock Exchange are categorized as insiders from 2005 to 2007, using the standard event study methodology. The study confirmed positive and significant abnormal returns for those who hold securities in portfolio based on insider information, thus exploiting market information to their advantage.

But Maheu and McCurdy (2007) investigated a conditional version of risk-return specification employing non-parametric measure of ex-post variance called realized volatility (RV), which was constructed using daily squared excess returns. The authors introduced a new volatility forecasting function based on exponential smoothing essentially to manage the noise and adopted the component GARCH approach applied by Engle and Lee (1999) to squared returns. They investigated whether total market risk or some component of it is priced and which component of the volatility best explains the dynamics of equity risk premium over the period $1840-2006$. Using a generalized univariate risk-return model for the market equity premium by estimating a bivariate stochastic specification of annual excess returns and the logarithm of realized volatility, they found a significant positive relationship between market risk and the market-wide equity premium, thus supporting earlier conclusions that the higher the expected market risk the higher the market equity premium.

The literature reviewed showed that whereas emphasis on information efficiency is presumed to be central to investors not been able to make abnormal returns, it was discovered in some of the studies that even in a well-developed market like the U.S. investors could beat the market because of insider knowledge. It is in the context of these notable findings that this study attempts to provide answers to the question whether investors cannot make abnormal returns in an emerging market like Nigeria.

\section{Methodology}

The hypothesis on determining whether investors can make abnormal returns was tested based on the work of Adams, et al (1993) which estimated the stock beta, determined the average risk free and computed the benchmark return using the formula given below:

$$
R_{s t}=\left(1-\beta_{s}\right) R_{f}+\beta_{s} R_{m t}
$$

We further computed the abnormal return for each stock using the formula given by Adams, et al (1993) as follows.

$$
\left[\mu_{i t}=R_{s t^{-}}\left(1-\beta_{s}\right) R_{f}+\beta_{s} R_{m t}\right]
$$

This is deduced from the general formula for the expected rate of return on a security given as:

$$
R_{s t}=\left(1-\beta_{s}\right) R_{f}+\beta_{s} R_{m t}+\mu_{i t}
$$

Where:

$R_{s t}=$ return on security at time $\mathrm{t}$

$\beta_{s} \quad=$ beta of individual stock

$R_{f} \quad=$ risk free rate

$R_{m t}=$ return on the market

$\mu_{i t} \quad=$ error term 
Brooks (2008) reported that Jensen (1968) also adopted this approach in carrying out a test of performance of mutual funds to examine whether any could beat the market. In order to determine the statistical significance of the results of the abnormal returns, the study employed both the Z-statistics critical value and the t-statistics critical value to determine their significance. The determination of abnormal returns is thus set in a tabular form.

The CAPM induced a priori statement that there is higher reward to higher risk which implies investors can make abnormal returns can only hold if the estimated values of â and $\hat{a}_{1}$ in equation 4 below are 0 and $>0$ respectively, i.e. $R_{i}=\hat{a}+\hat{a}_{1} R_{m}$

$$
\hat{a}_{0}=0, \hat{a}_{1}>0
$$

For purposes of detailed evaluation the study period was divided into three (3) sub-periods of 2 years each to permit both cross-periodic analysis as well as the overall study period of 2006 to 2011.

\subsection{Data}

Daily stock prices for the 85 quoted companies that made up the sample size was downloaded in microsoft excel format from the website of of the Central Securities and Clearing System (CSCS) and converted into monthly returns. The Nigerians Stock Exchange All Shares Index data from the fat book of the Nigerian Stock Exchange sevre as the proxy for market return.

\section{Results and Discussion}

\subsection{Testing whether Investors Can Make Abnormal Returns}

In testing whether investors in Nigerian capital market can make abnormal returns, we essentially computed abnormal returns relying upon the formula provided by Adams, et al (1993) to calculate both the benchmark and abnormal returns for the sub-periods (i.e. 2006-2007; 2008-2009; 2010-2011). We consequently verified if the computed returns are statistically significant at a 95 per cent confidence level. The findings/results are presented in Table 1 below.

Table 1. Results of the computed values of average abnormal returns and their corresponding Z-values for the three sub periods

\begin{tabular}{|c|c|c|c|c|c|c|}
\hline \multirow[t]{2}{*}{ Month } & \multicolumn{2}{|c|}{$2006-2007$} & \multicolumn{2}{|c|}{$2008-2009$} & \multicolumn{2}{|c|}{$2010-2011$} \\
\hline & AAB & $\mathrm{Z}$-value & $\mathrm{AAB}$ & $Z$-value & AAB & $\mathrm{Z}$-value \\
\hline Jan & 0.02 & 1.96 & 0.12 & 1.94 & 0.03 & 2.00 \\
\hline Feb & 0.06 & 2,01 & 0.32 & 2.00 & $0 . .2$ & 2.00 \\
\hline Mar & 0.03 & 2.01 & 0.08 & 2.01 & 0.05 & 2.01 \\
\hline Apr & 0.02 & 1.93 & 0.05 & 1.99 & 0.05 & 1.99 \\
\hline May & 0.07 & 2.01 & 0.05 & 1.75 & 0.02 & 2.01 \\
\hline Jun & 0.03 & 1.99 & 0.02 & 1.97 & 0.03 & 2.01 \\
\hline Jul & 0.07 & 1.98 & 0.04 & 2.01 & 0.02 & 2.01 \\
\hline Aug & 0.11 & 2.00 & 0.02 & 2.01 & 0.03 & 2.01 \\
\hline Sept & 0.07 & 2.00 & 0.03 & 2.00 & 0.03 & 2.00 \\
\hline Oct & 0.06 & 1.70 & 0.02 & 1.96 & 0.02 & 1.94 \\
\hline Nov & 0.03 & 1.99 & 0.03 & 1.99 & 0.02 & 2.00 \\
\hline Dec & 0.04 & 1.96 & 0.03 & 1.99 & 0.02 & 2.00 \\
\hline Jan & 0.09 & 1.99 & 0.06 & 1.96 & 0.02 & 2.01 \\
\hline Feb & 0.30 & 2.00 & 0.08 & 1.99 & 0.02 & 1.99 \\
\hline Mar & 0.10 & 2.01 & 0.05 & 1.96 & 0.01 & 1.90 \\
\hline Apr & 0.09 & 1.99 & 0.09 & 2.00 & 0.02 & 1.96 \\
\hline May & 0.14 & 2.00 & 0.24 & 1.94 & 0.02 & 2.00 \\
\hline Jun & 0.09 & 1.91 & 0.06 & 2.00 & 0.02 & 1.99 \\
\hline Jul & 0.06 & 2.01 & 0.02 & 1.99 & 0.01 & 1.99 \\
\hline Aug & 0.03 & 2.00 & 0.02 & 2.01 & 0.02 & 1.98 \\
\hline Sept & 0.03 & 2.01 & 0.07 & 1.96 & 0.04 & 1.99 \\
\hline Oct & 0.03 & 2.01 & 0.03 & 2.01 & 0.03 & 1.98 \\
\hline Nov & 0.05 & 2.00 & 0.02 & 2.00 & 0.03 & 1.98 \\
\hline Dec & 0.08 & 2.01 & 0.03 & 2.00 & 0.30 & 2.00 \\
\hline
\end{tabular}

Note: The critical Z-statistics/value at $\alpha$-value of 0.05 is pegged at 1.645

Source: Author's computation 
The results presented in Table 1 reveal that the computed average abnormal returns of the three different sub-periods are close to zero only in the sub-period 2010-2011. The sub-periods of 2006-2007 and 2008-2009 show that averagely the computed values were closer to 1 . In these periods, the market recorded average abnormal returns of $6 \%, 7 \%, 9 \%, 30 \%, 10 \%, 9 \%, 14 \%$ and $9 \%$ for most of the months in the sub-periods. In 2006, the market recorded an average abnormal return of between $6 \%$ and $11 \%$. However, this trend changed immediately afterwards as the average monthly returns became inconsistent and unpredictable and peaked at as high as $14 \%$ above the average market return in 2007. In the sub-period 2008-2009, investors recorded between 5\% to $32 \%$ abnormal returns above the average for a total of 12 months. It recorded $2 \%$ - 5\% returns for the remaining 12 months within this period. In the 2010-2011 sub-period however, the market recorded abnormal returns of 5\% and 30\% above the market average in only three months (March and April, 2010 and December 2011).

However, in proffering an answer to the question whether investors could make abnormal returns or testing the null hypothesis that says investors in Nigerian capital market cannot make abnormal returns, we computed the Z-statistics for abnormal returns and compared them with the critical z-value of 1.64 at alpha value of 0.05 or 5 percent. The computed Z-statistics range from an approximate value of 1.70 to 2.01 . Therefore given a critical value of 1.645 , we reject the null hypothesis that investors cannot make abnormal returns at the 95 percent confidence level.

The study further examines the overall sampling period of 2006-2011. This is to deduce a period-wide validation of the null hypothesis that says investors in the Nigerian capital market cannot make abnormal returns. The results are presented in Table 2 below.

Table 2. Results of computed average monthly abnormal returns and their corresponding Z-statistics for the overall study period 2006-2011

\begin{tabular}{|c|c|c|}
\hline \multirow[t]{2}{*}{ Month } & \multicolumn{2}{|c|}{ 2006-2011 Overall period } \\
\hline & $\mathrm{AAB}$ & z-value \\
\hline Jan '06 & 0.02 & 1.98 \\
\hline Feb '06 & 0.07 & 2.00 \\
\hline Mar '06 & 0.03 & 2.01 \\
\hline Apr '06 & 0.02 & 2.01 \\
\hline May '06 & 0.07 & 2.01 \\
\hline Jun '06 & 0.04 & 2.00 \\
\hline Jul '06 & 0.08 & 1.99 \\
\hline Aug '06 & 0.13 & 2.00 \\
\hline Sept '06 & 0.07 & 2.01 \\
\hline Oct '06 & 0.04 & 2.00 \\
\hline Nov '06 & 0.03 & 2.01 \\
\hline Dec '06 & 0.04 & 1.97 \\
\hline Jan '07 & 0.09 & 2.00 \\
\hline Feb '07 & 0.34 & 2.00 \\
\hline Mar '07 & 0.12 & 2.01 \\
\hline Apr '07 & 0.12 & 2.01 \\
\hline May '07 & 0.16 & 2.01 \\
\hline Jun '07 & 0.10 & 1.91 \\
\hline Jul '07 & 0.05 & 2.01 \\
\hline Aug '07 & 0.03 & 2.01 \\
\hline Sept '07 & 0.03 & 2.01 \\
\hline Oct '07 & 0.03 & 2.00 \\
\hline Nov '07 & 0.05 & 2.01 \\
\hline Dec '07 & 0.08 & 2.01 \\
\hline Jan '08 & 0.13 & 2.01 \\
\hline Feb '08 & 0.36 & 2.00 \\
\hline Mar '08 & 0.10 & 2.01 \\
\hline Apr '08 & 0.05 & 2.00 \\
\hline May '08 & 0.04 & 2.00 \\
\hline
\end{tabular}




\begin{tabular}{|c|c|c|}
\hline Jun '08 & 0.02 & 1.98 \\
\hline Jul '08 & 0.04 & 1,99 \\
\hline Aug '08 & $0 . .06$ & 1.97 \\
\hline Sept '08 & 0.02 & 2.00 \\
\hline Oct '08 & 0.03 & 1.96 \\
\hline Nov '08 & 0.04 & 2.00 \\
\hline Dec '08 & 0.03 & 2.00 \\
\hline Jan '09 & 0.06 & 2.00 \\
\hline $\begin{array}{ll}\text { Feb } & \text { '09 }\end{array}$ & 0.08 & 1.99 \\
\hline Mar '09 & 0.04 & 2.01 \\
\hline Apr '09 & 0.10 & 2.01 \\
\hline May '09 & 0.23 & 1.94 \\
\hline Jun '09 & 0.06 & 2.00 \\
\hline Jul '09 & 0.02 & 2.00 \\
\hline Aug '09 & 0.03 & 1.99 \\
\hline Sept '09 & 0.07 & 1.97 \\
\hline Oct '09 & 0.03 & 2.00 \\
\hline Nov '09 & 0.02 & 2.01 \\
\hline Dec '09 & 0.03 & 1.99 \\
\hline Jan '10 & 0.03 & 2.00 \\
\hline Feb ' 10 & 0.02 & 1.99 \\
\hline Mar ' 10 & 0.04 & 2.00 \\
\hline Apr ' 10 & 0.07 & 1.99 \\
\hline May '10 & 0.02 & 2.00 \\
\hline Jun '10 & 0.03 & 2.01 \\
\hline Jul '10 & 0.02 & 2.01 \\
\hline Aug ' 10 & 0.03 & 2.00 \\
\hline Sept ' 10 & 0.02 & 2.01 \\
\hline Oct ' 10 & 0.02 & 1.94 \\
\hline Nov ' 10 & 0.02 & 2.01 \\
\hline Dec ' 10 & 0.02 & 2.00 \\
\hline Jan '11 & 0.05 & 2.00 \\
\hline Feb '11 & 0.01 & 1.99 \\
\hline Mar '11 & 0.01 & 1.91 \\
\hline Apr ' 11 & 0.02 & 1.97 \\
\hline May '11 & 0.02 & 1.99 \\
\hline Jun '11 & 0.02 & 1.99 \\
\hline Jul '11 & 0.01 & 2.01 \\
\hline Aug '11 & 0.04 & 1.99 \\
\hline Sept '11 & 0.04 & 1.99 \\
\hline Oct '11 & 0.03 & 1.96 \\
\hline Nov ' 11 & 0.03 & 1.98 \\
\hline Dec '11 & 0.38 & 2.00 \\
\hline
\end{tabular}

Source: Author's computation

The results of the overall sampling period (2006-2011) shown in Table 2 above are similar to those of the sub-periods; the monthly average abnormal returns are relatively close to zero. However, in the early years of the study period particularly in 2006, 2007, and 2008, returns recorded appreciably large percentage figures in excess of the market average. It is more so in 2011 the market recorded as much as 38 percent abnormal returns. But in general returns are low, ranging between 2 percent and 4 percent most of time. The study also notes that the calculated $Z$-statistics range from 1.96 to 2.01, which is larger than the critical Z-statistics value of 1.645 at alpha value of 0.05 . Since the calculated Z-statistics value is larger than the critical Z-statistics there is sufficient evidence to reject the null hypothesis that investors in Nigerian capital market cannot make abnormal returns. 


\section{Conclusion and Recommendations}

The study attempts to provide answer to the question "can investors make abnormal returns in the Nigerian capital market consistently?" We employed non-parametric model which provides z-value that are larger than the critical z-value at $5 \%$ in both the sub-periods and overall period. This makes us to conclude that investors in the Nigerian capital market can make abnormal return significantly. Although the percentage performance values in some instances are relatively close to zero it however shows that investors recorded returns above the market average in all the months of the study period. This indicates a consistent trend. This is consistent with a priori where $\hat{a}_{1}>0$. Thus, we can conclude that investors can make abnormal returns consistently in the market, meaning that investors can consistently outperform the market.

Based on these findings we recommend strict compliance with extent rules and policies guiding the conduct of activities in the Nigerian capital market. Stiff sanctions should be applied to market participants who indulge in underhand deals and transactions; transparency in market activities is essential to deepen market operations to position it as an attractive haven for investible funds. The leadership of the Nigerian capital market should provide mechanisms that can foster transparency and efficiency. As part of the strategy to deepen market operations the monetary authorities should recourse to medium term bonds as sources of government borrowing to boost and leverage market capitalization and performance. Such deliberate intervention to deepen market activities could serves as incentives for accelerated pool of resources from both domestic and foreign investors.

\section{References}

Adams, A., Bloomfield, D., Booth, P., \& England, P. (1993). Investment mathematics and statistics. Kluwer Academic Publishers Group, Norwell, Massachusetts, USA.

Adelegan, O. J. (2009). Price reactions to dividend announcements on the Nigerian capital market.AERC Research Paper 188. Retrieved from Price Reactions to Dividend Announcement NCM.pdf - Adobe Reader

Ayadi, O. (1984). The random walk hypothesis and the behavior of share prices in Nigeria. The Nigerian Journal of Economics and Social Studies, 26(1), 57-71.

Brooks, C. (2008). Introductory econometrics for finance ( $2^{\text {nd }}$ ed.). Cambridge, UK. Cambridge University Press.

Dogu, M., Karacaer, S., \& Karan, M. B (2010). Empirical testing of insider trading in the Istanbul stock exchange. International Research Journal of Finance and Economics, 15, 97-107. Retrieved from http://www.eurojournals.com/finance.htm

Echekoba, F. N., \& Ezu, G. K. (2012). Efficient Market Hypothesis: A historical perspective (A study of Nigerian capital market). Kuwait Chapter of Arabian Journal of Business and Management Review, 1(8), 76-86

Emenike, K. O. (2008). Efficieny across time: Evidence from the Nigerian stock exchange. Retrieved from http://mpra.ub.uni-muenchen.de/22901/MPRA

Fama, E. G. (1965). Random walks in stock-market prices. Journal of Business. Retrieved from http://www.chicagobooth.edu/faculty/selectedpapers/sp16.pdf

Jensen, M. C. (1978). Some anomalous evidence regarding market efficiency. Journal of Financial Economics, $6(2 / 3), 95-101$.

Maheu, J. M., \& McCurdy, T. H. (2007). Components of market risk and return. Journal of Financial Econometrics, $5(4), 560-590$.

Ogege, S., \& Ezike, J. E. (2012). The Nigerian capital market and economic development: A critical appraisal. International Business Research, 5(8), 228-236.

Olowe, R. A. (1998). Stock splits and efficiency of the Nigerian stock market. African Review of Money, Finance and Banking. Retrieved from www.jstor.org/stable/23026306

Seyhun, H. N. (1986). Insiders' profit, cost of trading and market efficiency. Journal of Financial Economics, 16, 189-212.

Ziobrowski, A. J., Boyd, J. W., Cheng, P., \& Ziobrowski, B. J. (2011). Abnormal returns from the common stock investment of members of the U. S. House of Representatives. Business and Politics, 13(1). Retrieved from http://www.bepress.com/bap/vol13/iss1/art4 